Endocrinol. Japon. 1989, 36 (1), 117-124

\title{
Ectopic Production of Renin by Ileal Carcinoma
}

\author{
Toshikazu SAITO ${ }^{1)}$, Akiyoshi FUKAMIZU ${ }^{2)}$, Koji OKADA ${ }^{1)}$ \\ SAN-E ISHIKAWA ${ }^{1)}$, Yasuhiko IWAMOTO ${ }^{1)}$, TAKeshi KUZUYA ${ }^{1)}$, \\ Toshiro KAWAI ${ }^{3)}$, Kiyoko NARUSE ${ }^{4)}$, SHIgeHISA HIROSE ${ }^{2)}$ \\ AND KAZUO MURAKAMI ${ }^{2)}$ \\ 1) Division of Endocrinology and Metabolism, Department of Medicine, \\ Jichi Medical School, ${ }^{2)}$ Institute of Applied Biochemistry, University \\ of Tsukuba, ${ }^{3)}$ Department of Pathology, Jichi Medical School, \\ 4) Department of Medicine, Tokyo Woman's Medical College
}

\begin{abstract}
A 54-yr-old woman with the symptoms of primary reninism, i. e. hypertension, metabolic alkalosis and elevated levels of plasma renin activity (PRA) and aldosterone, is described. She had an ileal cancer secreting active and inactive renin. The symptoms markedly improved after resection of the tumor. In the tumor active and inactive renin were proved to be present by an assay of angiotnesin $I$ formation in the presence and absence of renin antibody, and renin immunoreactivity was found immunohistochemically. The mRNA coding for the renin precursor was identified in the RNA-rich extract of the tumor by blot hybridization analysis with the human renin cDNA as a probe. The mRNA from the tumor was shown to be identical in molecular size to that from the human kidney by agarose gel electrophoresis. This is the first description of an ectopic renin-producing ileal carcinoma and the first demonstration of renin mRNA in the tumor tissue.
\end{abstract}

Renal tumor such as juxtaglomerular cell tumor (Robertson et al., 1967 ; Baruch et al., 1984), Wilms' tumor (Sheth et al., 1978) or renal carcinoma (Hollifield et al., 1975; Leckie et al., 1978) can sometimes produce renin in the tumor tissue and cause symptoms of hyperaldosteronism due to primary hyperreninism. In cases of the ectopic production of various hormones by neoplastic tissues, only a few extra-renal

Received October 4, 1988

Address reprint requests to Dr. TOSHIKAZU SAITO, Division of Endocrinology and Metabolism, Jichi Medical School, Minamikawachimachi, Kawachi-gun, Tochigi-ken 329-04, Japan. tumors have hitherto been reported that produced renin. These include lung cancer (Genest et al., 1975), pancreas cancer (Ruddy et al., 1982), para-ovarian tumor (Aurell et al., 1979), orbita tumor (Yokoyama et al., 1979) and ovarian Sertoli cell tumor (Korzets et al., 1986). An ectopic reninproducing tumor arising from the gastrointestinal tract, however, has not been reported yet. Further, direct evidence indicating the process of renin biosynthesis has not been shown in any of these tumors.

The present report describes ectopic production of renin by an ileal carcinoma. The presence of active and inactive renin 
in the tumor tissue was proved by a specific assay, and the immunohistochemical staining for renin revealed the presence of immunoreactive renin in the tissues. The biosynthesis of renin was confirmed by the demonstration of mRNA coding for the renin precursor in the tumor tissue.

\section{Subjects and Methods}

\section{Case report}

A 54-year-old woman was admitted to Jichi Medical School Hospital with the chief complaints of an abdominal mass and emaciation in December, 1984. Four years earlier she had diabetes mellitus and had been treated with oral hypoglycemic agents. One month before her admission to the hospital she began to loose body weight, going from $50 \mathrm{Kg}$ to $46 \mathrm{Kg}$ in a month. She also noticed two hard abdominal masses. She had never shown signs of hypertension previously. On admission a physical examination revealed an emaciated woman with a blood pressure of $185 / 100$. Two hard masses, $5 \times 8 \mathrm{~cm}$ in size, were palpable in the epigastric and right lower quadrant of her abdomen. Routine laboratory findings included a serum sodium level of $140 \mathrm{mEq} / 1$ and a potassium level of $2.5 \mathrm{mEq} / 1$. The gas analysis of her arterial blood revealed a $\mathrm{pH}$ of 7.516 and a
$\mathrm{HCO}_{3}$ of $35.5 \mathrm{mEq} / \mathrm{l}$, indicating metabolic alkalosis. Urinary excretion of potassium was $24 \mathrm{mEq} /$ day. An Abdominal echogram, an angiography of the ileal artery, and a scintigram by ${ }^{204} \mathrm{Ga}$ uptake revealed two abdominal masses which were consistent with the palpatory findings. The intravenous pyelography revealed no abnormality in the kidneys. After 30 minutes recumbency, PRA was $29.0 \mathrm{ng} / \mathrm{ml} / \mathrm{hr}$, the aldosterone concentration was $14.2 \mathrm{ng} / \mathrm{dl}$ and angiotensin II (AII) was $310 \mathrm{pg} / \mathrm{ml}$. In a furosemide loading test, the levels of PRA before and after intravenous infusion of furosemide (1 $\mathrm{mg} / \mathrm{kg}$ body weight) and standing for 2 hours were $43.0 \mathrm{ng} / \mathrm{ml} / \mathrm{hr}$ and $35.9 \mathrm{ng} / \mathrm{ml} / \mathrm{hr}$ respectively. An intravenous infusion of $\mathrm{Sar}^{1} \mathrm{Ile}^{8}$ AII resulted in a rapid fall in blood pressure (Fig. 1). The PRA levels before and after infusion of $\mathrm{Sar}^{1} \mathrm{Ile}^{8}$ AII were 36.4 and 30.9 $\mathrm{ng} / \mathrm{ml} / \mathrm{hr}$, respectively. Plasma ACTH was 41.5 $\mathrm{pg} / \mathrm{ml}$ and cortisol was $21.9 \mu \mathrm{g} / \mathrm{dl}$ The plasma level of carcinoembryonic antigen was $80.2 \mathrm{ng} / \mathrm{ml}$ (normal: <5). Laparotomy showed that the tumor, originating in the terminal portion of the ileum, had spread to the pancreatic region. No infiltration to the kidneys or oppression of the renal artery by the tumor was seen.

Approximately two thirds of the tumor was surgically removed and a histological study revealed a poorly differentiated adenocarcinoma. After the operation the blood pressure fell to $135 / 85$ without treatment with anti-hypertensive

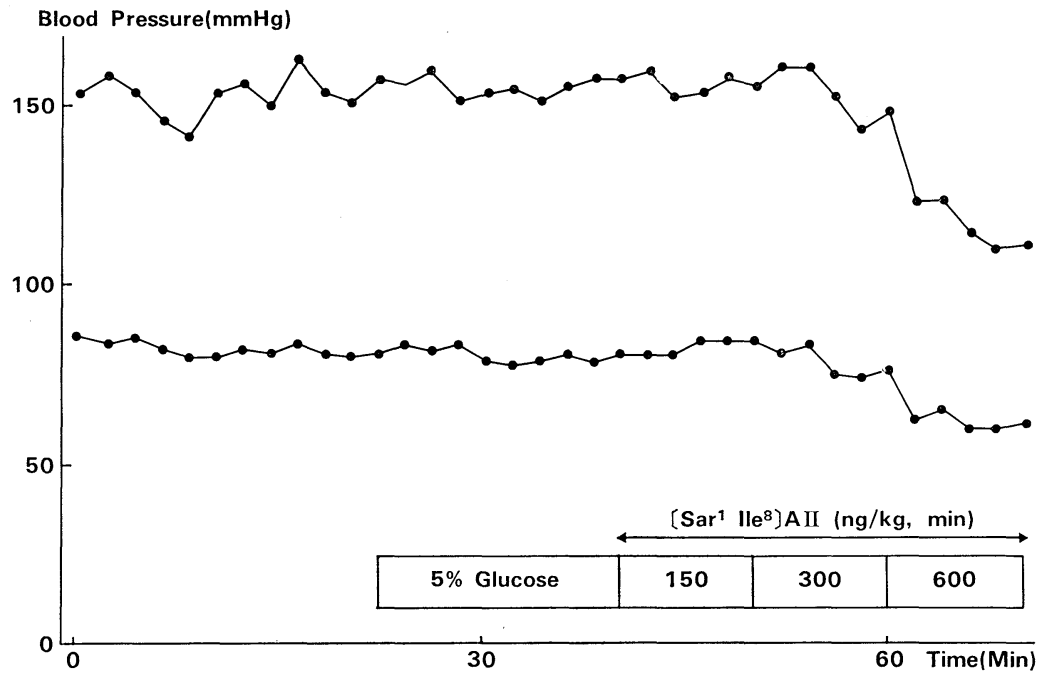

Fig. 1. The effect of infusion of $\mathrm{Sar}^{1} \mathrm{Ile}^{8}$ AII on the systolic and diastolic blood pressure. After the infusion of $5 \%$ glucose solution as a vehicle for 15 minutes, the AII analogue was infused at the rate of 150 , 300 or $600 \mathrm{ng} / \mathrm{kg} / \mathrm{min}$ for 10 minutes. The arterial blood pressure was determinined at the antecubital artery with an electronic sphygmomanometer at 2 minute intervals. 
drugs. The patient was discharged from the hospital and her state of health remained unchanged for four months. She gradually became cachectic and nine months after the operation she was readmitted to the hospital because of cachectic emaciation and died two weeks later. A postmortem examinantion revealed a postoperative state of ileal cancer, peritonitis carcinomatosa, a conglomated tumor mass that had spread from the pelvic cavity to the pancreas. The renal arteries on both sides were intact and the kidneys had a slightly dliated pelvis. The histological examination of the kidney showed nodular glomerulosclerosis which was compatible with diabetic nephropathy, with a normal juxtaglomerular apparatus. The adrenal cortices on both sides were macroscopically and histologically normal.

\section{Assay of $P R A$ and renin activity in the tumor tissue}

PRA was measured by conventional radioimmunoassay of the angiotensin I generated during 1-hour incubation of plasma samples with an endogenous renin substrate at $\mathrm{pH} 5.7$ using commercial kits. The concentrations of active and inactive renin in plasma were assayed as described previously (Goto et al., 1984). Inactive renin was activated by mixing the plasma $(1 \mathrm{ml})$ with $10 \mu \mathrm{l}$ of trypsin solution $(8 \mathrm{mg} / \mathrm{ml}$ in $0.001 \mathrm{~N}$ $\mathrm{HCI}$ ) and incubating this for 5 minutes at $4^{\circ} \mathrm{C}$. Concentrations of active and total renin in plasma were measured by determining the rate of angiotensin I formation when original or activated plasma was incubated with an excess of sheep renin substrate, respectively. The inactive renin concentration was defined as the difference between the total and active renin concentrations in plasma. Renin activities in the tumor tissue and the adjacent intact tissue of the ileum, which were obtained at operation, were assayed as described earlier (Murakami et at., 1980). The renin activity was determined by the rate of formation of angiotensin I from hog renin substrate. The tissue was homogenized in a $0.01 \mathrm{M}$ sodium pyrophosphate buffer, $\mathrm{pH} 6.5$ containing $0.1 \mathrm{M} \mathrm{NaCl}$ and centrifuged at $100,000 \mathrm{~g}$ for 60 minutes. The supernatant was used as a tissue extract for renin assay. Inactive renin in the tissue extract was determined as in the plasma sample by tryspinization. The specificity of the renin activity was confirmed by assaying the angiotensin $I$ generation in the presence and absence of the antibody to human renin (Hirose et al., 1980).

\section{Immunohistochemical study of renin in the tissue}

Anti-human renin antiserum (Yokosawa et at., 1980a) and purfied human renal renin (Yokosawa et al., 1980b) for the immunohistochemical study were supplied by Dr. T. Inagami (Vanderbilt University School of Medicine, Tennessee). Tumor tissue obtained during the operation was fixed by immersion in Bouin's fixative, dehydrated, and embedded in paraffin. Four-micron-thick sections were stained immunohistochemically for renin by the avidinbiotin-complex method (Hus et al., 1981). Staining specificity was verified by substituting non-immune rabbit serum as well as by prior absorption of antiserum with an excess of purified human renal renin $(10 \mu \mathrm{g} / \mathrm{ml})$ for the primary antiserum:

\section{Analysis of mRNA for renin biosynthesis}

mRNA for renin biosynthesis was studied in the tumor tissue obtained at the operation and the normal renal tissue obtained from a patient having a renal operation. Total RNA was isolated from the tumor tissue by the procedure of Chirgwin et al. (Chirgwin et al., (1979). Briefly, the RNA was enriched for poly (A) ${ }^{+}$-RNA containing sequences by two passages over oligo (dT)-cellulose. RNA isolated from the tumor tissue, the intact ileum obtained at the operation, and the renal tissue from a patient undergoing a renal operation served as negative and positive control preparations for RNA, respectively. The poly (A) ${ }^{+}-$RNAs were denaturated with $1 \mathrm{M}$ glyoxal and $50 \%$ dimethylsulfoxide (Mac Master et al. 1977), electrophoresed on a $1.2 \%$ agarose gel and transferred to diazobenzyl oxymethyl-paper prehybridized at $42^{\circ} \mathrm{C}$ for 20 hours in $50 \%$ formamide, $\quad 0.75 \mathrm{M} \mathrm{NaCl}, \quad 0.075 \mathrm{M}$ sodium citrate, $50 \mathrm{mM}$ sodium phosphate buffer $\mathrm{pH} 6.8$, $0.02 \%$ Ficoll, $0.02 \%$ bovine serum albumin, $1 \%$ glycine, $0.2 \%$ sodium dodesyl sulphate and $1 \mathrm{mg} / \mathrm{ml}$ denaturated salmon sperm DNA. The paper was hybridized at $42^{\circ} \mathrm{C}$ for 52 hours in the same solution, except that glycine was omitted. The hybridization probe used was an AvaII-AvaII fragment excised from the insert of plasmid pHRn321 (Imai et al., 1983) carrying cDNA for the renin precursor. The DNA frag- 
ment was labelled with $\left[\alpha^{32} \mathrm{P}\right] \mathrm{dCTP}$ by nick translation (Rigby et al. 1977) to a specific activity of $2.5 \times 10^{8} \mathrm{cpm} / \mu \mathrm{g}$. After the hybridization, the paper was washed at $42^{\circ} \mathrm{C}$ for $4 \mathrm{hr}$ in $50 \%$ formamide, $0.75 \mathrm{M} \mathrm{NaCl}, 0.075 \mathrm{M}$ sodium citrate, $25 \mathrm{mM}$ sodium phosphate buffer, $\mathrm{pH}$ 6.8, and autoradiographed at $-70^{\circ} \mathrm{C}$ with an intensifying screen.

\section{Results}

\section{Clinical course}

The courses of plasma renin activity, plasma aldosterone concentration, potassium level in plasma, and blood pressure are shown in Fig. 2. After administration of $75 \mathrm{mg} /$ day of spironolactone, the serum level of potassium rose from $2.5 \mathrm{mEq} / 1$ to 3.5 $\mathrm{mEq} / 1$ and the blood pressure fell to $145 / 70$ mmHg. The partial resection of the ileal tumor resulted in the fall of PRA from
$36.4 \mathrm{ng} / \mathrm{ml} / \mathrm{hr}$ to $4.2 \mathrm{ng} / \mathrm{ml} / \mathrm{hr}$ in 8 hours. The blood pressure and PRA rose again gradually and at the time of readmission the blood pressure was $165 / 95$, the PRA was $39.0 \mathrm{ng} / \mathrm{ml} / \mathrm{hr}$ and the plasma aldosterone concentration was $34.7 \mathrm{ng} / \mathrm{dl}$.

\section{Renin concentration in plasma and the tissue}

The day before the operation, concentrations of active and inactive renin in plasma assayed in the presence of sheep renin substrate were $19.3 \mathrm{ng} / \mathrm{ml} / \mathrm{h}$ (normal: $2.9 \pm 0.4$ ) and $89.7 \mathrm{ng} / \mathrm{ml} / \mathrm{h}$ (normal : 33.9土 6.1 , respectively.

The extract from the ileal tumor obtained during the operation showed a a renin activity of $114 \mathrm{ng} / \mathrm{mg}$ protein $/ \mathrm{hr}$ and inactive renin concentration of $214 \mathrm{ng} /$ $\mathrm{mg}$ protein $/ \mathrm{hr}$. The renin activity of the tumor extract was strikingly suppressed to
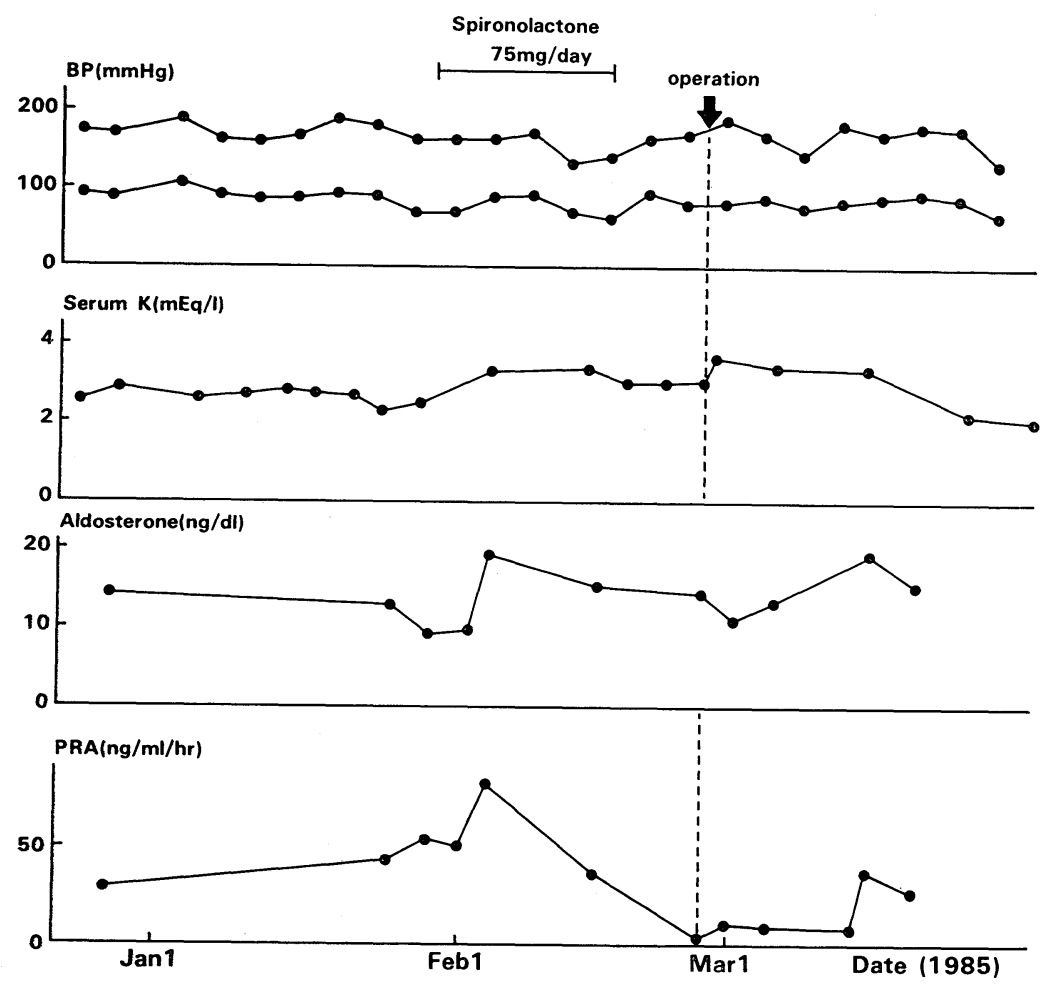

Fig. 2. Hospital course of the systolic and diastolic blood pressure, serum potassium, plasma aldosterone concentration and plasma renin activity. Samples on the day of operation were taken 8 hours after the tumor resection. 


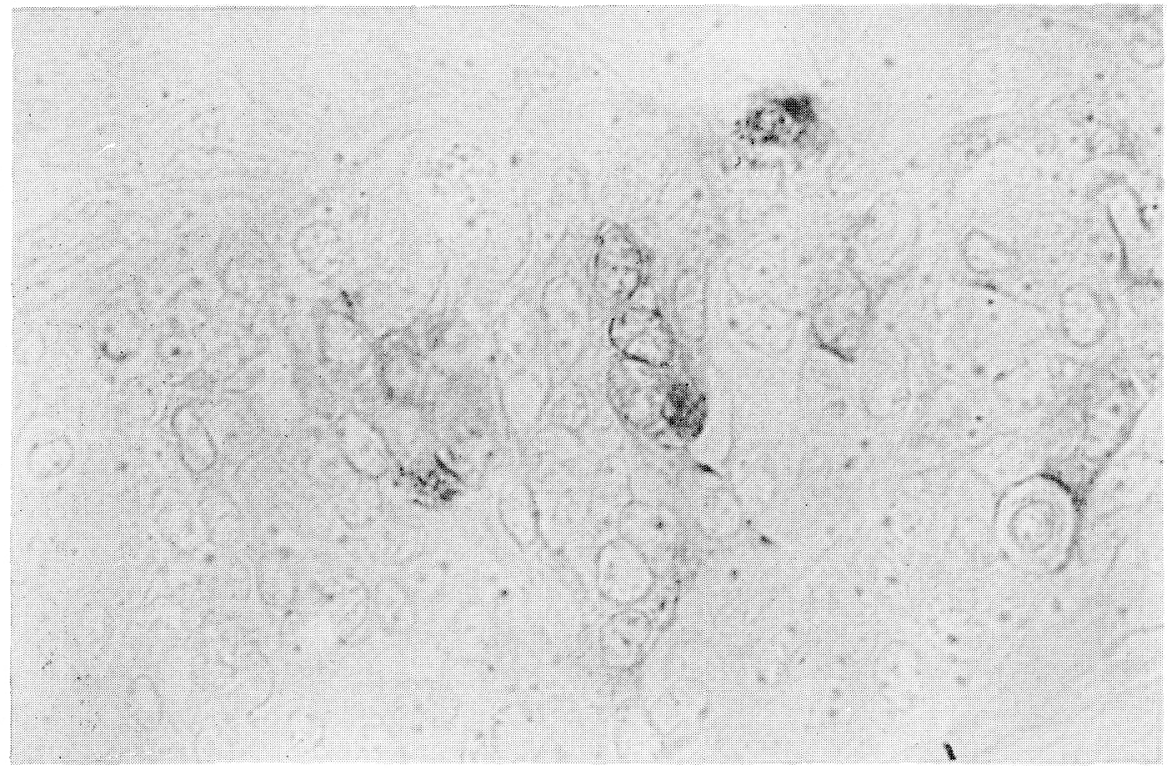

Fig. 3. Immunohistochemical staining for renin of the tumor tissue. The ileal tumor tissue obtained during the operation was stained with antihuman renin antiserum by the avidinbiotin-complex method (magnification $670 \times$ ).

$1.25 \mathrm{ng} / \mathrm{mg}$ protein $/ \mathrm{hr}$ after treatment with antibody to human renin. The renin activity of the extract from the intact tissue of the ileum adjacent to the tumor was as low as $0.45 \mathrm{ng} / \mathrm{mg}$ protein $/ \mathrm{hr}$.

\section{Histological findings in the tumor}

A histological examination of the tumor revealed an undifferentiated small cell carcinoma. An immunohistochemical study for renin revealed an intense cytoplasmic immunoreactivity in the carcinomatous cells (Fig. 3). The specificity of the staining reaction was demonstrated by the complete absence of staining when either normal rabbit serum or antiserum, preabsorbed with excess renin, was substituted for antiserum. On electron microscopy, the tumor cells displayed the findings of adenocarcinoma composed of mucous droplets, microvilli, intracellular lumen, and terminal bars. But no crystalline or rhomboid granules, which are observed in juxtaglome- rular cells, could be identified.

\section{mRNA for the renin precursor}

The autoradiogram of the blot hybridization analysis for the mRNA in the normal kidney, tumor tissue, and the intact intestinal tissue from the patient is shown in Fig. 4. A single predominant species of RNA was detected in the tumor tissue (lane 2) and in normal kidney (lane 1). A control RNA preparation obtained from the patient's small intestine, which does not produce renin, yielded no hybridizationpositive band (lane 3).

\section{Discussion}

The present case shown the striking symptoms of primary reninism including elevated PRA and the concentration of inactive renin in plasma, hypokalemia, metabolic alkalosis, and hypertension. The 


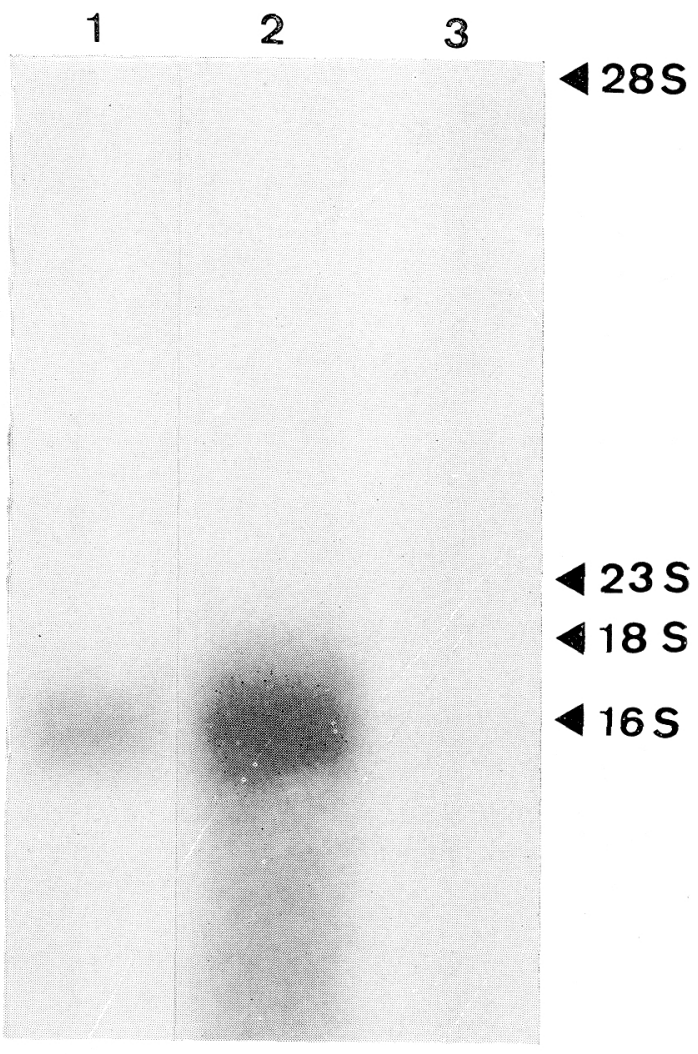

Fig. 4. Blot hybridization analysis of kidney and lieal carcinoma mRNA. Twenty micrograms of poly $(\mathrm{A})^{+}$-RNA were applied to each lane. 1, normal kidney mRNA; lane 2, ileal carcinoma mRNA; and, lane 3 , intact ileum mRNA from adjacent portion. The positions of the size markers are indicated.

clinical course was similar to that of renovascular hypertension. The involvement of renovascular stenosis, however, is unlikely, since no obstruction or oppression by the tumor was seen in the renal arteries on either side at autopsy as presumed from the findings of intravenous pyelography and the operation. The fall in blood pressure and the improvement of clinical findings of primary reninism after resection of the tumor seem to support the idea that the main source of the PRA was ileal cancer, as reported in the cases of paraovarian tumor (Aurell et al., 1979) and ovarian Sertoli cell tumor (Korzetes et al., 1986).

As cathepsin $\mathrm{D}$ is known to generate angiotensin I from tetradecapeptide renin substrate (Hackenthal et al., 1978), the possibility has not been excluded that the renin-like activity observed in the tumors tissue in previous reports of ectopic renin production (Genest et al., 1975; Ruddy et al., 1982; Aurell et al., 1979; Yokoyama et al., 1979; Korezets et al., 1986) resulted from enzyme other than renin. Complete elimination of the renin activity by the highly specific renin antibody in the present study confirmed the presence of renin in the tissue. The finding of the immunohistochemical staining further support this conclusion. The absence of granules as observed in the juxtaglomerular cells in the electron-micrograph may not be inconsistent with the ectopic renin production in the tumor tissue as reported in cases of insulin producing B cell tumors of the pancreas (Creutzfeld et al., 1973).

The result of blot hybridization analysis, with the human renin precursor cDNA as a probe, shows that the ileal tumor in the patient contained one hybridization-positive RNA species and that the transcription process for pro-renin biosynthesis was present in the tumor tissue. The mRNA was identical in molecular size to the hybridization-positive RNA species from human kidney as far as the pattern of agarose gel electrophoresis shows.

In the tumor tissue in the present case, the inactive renin which is activated by trypsinization, was found in addition to active renin as reported in the cases of renal carcinoma (Leckie et al., 1978) and adenocarcinoma of the pancreas (Ruddy et al., 1982), presumably as a product of the identified renin mRNA. In the latter case reported by Ruddy et al., the percentage of inactive portion in the total renin in plasma was extremely high at $98 \%$. This percentage, however, was $82.3 \%$ in the present 
case which was similar to normal subjects (Goto et al., 1984). It is suggested that percentage of inactive renin in plasma in such patients varies from case to case and may not be a useful indicator of ectopic renin production.

The elevated levels of AII in plasma and the rapid fall in blood pressure after intravenous administration of AII antagonist in this study indicate the involvement of AII in the maintenance of high blood pressure. As reported in the case with a para-ovarian renin-producing tumor (Aurell et al., 1979), in which the adminstration of a converting enzyme inhibitor caused a rapid fall in blood pressure, the high blood pressure in the present case may, at least in part, have resulted from the vasoconstricting effect of AII due to hyperreninism. The prolonged administration of spironolactone was also effective in lowering the high blood pressure in addition to reducing the hypokalemia associated with metabolic alkalosis. This fact suggests the significance of hyperaldosteronism in the development or maintenance of hypertension as well. The absence of an increase in the PRA during the fall in blood pressure during infusion of $\mathrm{Sar}^{1} \mathrm{Ile}^{8}$ AII, as well as in the furosemidestanding test, may indicate the lack of physiological control of renin release in the present patient, as reported in the case with an anaplastic lung carcinoma producing renin (Genest et al., 1975).

In conclusion, in a case of ileal carcinoma associated with clinical symptoms of primary reninism, which responded to the administration of $\mathrm{Sar}^{1} \mathrm{Ile}^{8}$ angiotensin II or spironolactone or the resection of the tumor, elevated levels of active and inactive rerin were proved to be present and renin immunoreactivity was seen immunohistochemically. The mRNA coding for a renin precursor, which has similar molecular size to that of a normal kidney, was identified in the tumor tissue, corresponding with the transcription process of ectopic renin biosynthesis.

\section{References}

Alwine, J. C., D. J. Kemp and G. R. Stark (1977). Method for detection of specific RNAs in agarose gels by transfer to diazobenzyloxymethyl-paper and hybridization with DNA probes. Proc. Natl. Acad. Sci. U. S. A. 74, 5350-5354.

Aurell, M., A. Rudin, L. E. Tisell, L. G. Kindbloom and G. Sanberg (1979). Captopril effect on hypertension in patient with renin-producing tumor. Lancet 2, 149-150.

Baruch, D., P. Corvol, F. Alhenc-Gelas, $M_{\mathbf{6}}$ A. Dufoux, T. T. Guyenne, J. C. Gaux, A. Raynaud, J. M. Bisset and J. Menard (1984). Diagnosis and treatment of renin-secreting tumors. Hypertension 6, 760-766.

Chirgwin, J. M., A. E. Przybyla, R. J. Mac Donald and W. J. Rutter (1979). Isolation of biologically active ribonucleic acid from sources enriched in ribonuclease. Biochemistry 18, 5294-5299.

Creutzfeld, W., R. Arnold, C. Creutzfeld, H. Deuticke, H. Frerichs and N. S. Track (1973), Biochemical and morphological investigations of 30 human insulinomas. Diabetologia, 9, 217-231.

Genest, J., J. M. Rojo-Ortega, O. Kuchel, R. Boucher, W. Nowaczynski, R. Lefebvrc, M. Chretien, J. Cantin and P. Granger (1975). Malignant hypertension with hypokalemia in a patient with renin-producing pulmonary carcinoma. Trans. Assoc. Am. Physician. 88, 192-201.

Goto, T., N. Imai, S. Hirose and K. Murakami (1984). An improved method for determination of active and total renin concentration in human plasma using an excess of sheep substrate. Clin. Chim. Acta 138, 87-98.

Hackenthal, E., R. Hackenthal and U. Hilgenteldt (1978). A comparative enzymatic study of angiotensin-forming enzymes. Biochim. Biophys. Acta 522, 574-588.

Hirose, S., H. Yokosawa, T. Inagami and R. J. Workman (1980). Renin and prorenin in hog brain: ubiquitous distribution and high concentration in the pituitary and pineal. Brain Res. 191, 489-499.

Hollifield, J. W., D. L. Page, C. Smith, A. M. Michelakis, E. Staab and R. Rhamy (1975). Renin-secreting clear cell carcinoma of the kidney. Arch. Int. Med. 135, 859-864. 
Hus, S. M., L. Raine and H. Fanger (1981). A comparative study of the RAP method and avian-biotin-complex method for studying polypeptide hormone. Am. J. Clin. Pathol. 75, 734-738.

Imai, T., H. Miyazaki, S. Hirose, H. Hori, T. Hayashi, R. Kageyama, H. Ohkubo, S. Nakanishi and K. Murakami (1983). Cloning and sequence analysis of cDNA for human renin prezursor. Proc. Natl. Acad. Sci. U.S.A. 80, 7405-7409.

Korzets, A., H. Nouriel, Z. Steiner, B. Griffel, L. Kraus. U. Freund and A. Klajman (1986). Resistant hypertension associated with a reninproducing ovarian Sertoli cell tumor. Am. $J$. Clin. Pathol. 85, 242-247.

Lezkie, B., J. J. Brown, R. Fraser, K. Kyle, A. F. Lever, J. J. Morton, and J. I. S. Robertson (1978). A renal carcinoma secreting inactive renin. Clin. Sci. Mol. Med. 55, 159s$161 s$.

MacMaster, G. K. and G. G. Carmichael (1977). Analysis of single- and double-stranded nucleic acids on polyacrylamide and agarose gels by using glyoxal and acridine orange. Proc. Natl. Acad. Sci. U. S. A. 74, 4835-4838.

Murakami, K., S. Takahashi, F. Suzuki, S. Hirose and T. Inagami (1980). Intemediate molecular weight renin and renin-binding protein(s) in the kidney. Biomedical Res. 1, 392-399.

Rigby, P. W. J., M. Dieckman, C. Rhodes and
P. Berg (1977). Labelling deoxyribonucleic acid to high specific activity in vitro by nick translation with DNA polymerase I. J. Mol. Biol. 113, 237-251.

Robertson, P. W., A. Klidjian, L. K. Harding, G. Walters, M. R. Lee and A. H. T. RobbSmith (1967). Hypertension due to a reninsecreting renal tumor. Am. J. Med. 43, 963976.

Ruddy, M. C., S. A. Atlas and F. G. Saleno (1982). Hypertension associated with a reninsecreting adenocarcinoma of the pancreas. N. Engl. J. Med. 307, 993-996.

Sheth, K. J., T. T. Tang, M. E. Blaedel and T. A. Good (1978). Polydipsia, polyuria and hypertension associated with renin-secreting Wilm's tumor. J. Paediatr. 92, 921-924.

Yokosawa, H., N. Yokosawa and T. Inagami (1980a). Specific antibody to human renal renin and its cross reactivity with inactive human plasma protein. Proc. Soc. Exp. Biol. 164, 466-470.

Yokosawa. H., L. A. Holladay, T. Inagami, E. Haas and K. Murakami (1980b). Human renal renin : complete purification and characterization. J. Biol. Chem. 255, 3498-3500.

Yokoyama, H., Y. Yamane, J. Takahara, T. Yoshinouchi and T. Ofuji (1979). A case of ectopic renin-secreting orbital hemanigiopericytoma assaciated with juvenil hypertension and hypokalemia. Acta Med. Okayama 33, 315322. 